\title{
Kearifan Lokal Masyarakat Kalimantan Tengah "Karungut Sansana Dayak" Sebagai Sumber Belajar IPS di Era Globalisasi
}

\author{
Ayu Fajriyah (Pendidikan IPS 2019)
}

\author{
1910128120009@mhs.ulm.ac.id
}

\begin{abstract}
Abstrak
Artikel ini mendeskripsikan kearifan lokal di Indonesia yaitu "Karungut Sansana Dayak" sebagai sumber belajar IPS dalam menghadapiera milenial. Era milenial sendiri ditandai mudahnya masyarakat mendapatkan informasi dari berbagai belahan dunia sebagai akibat dari perkembangan teknologi yang begitu pesat. Kondisi ini bukan hanya memberikan kontribusi positif bagi sebuah bangsa atau agregat social tertentu. Namun secara sekaligus ini memberikan dampak (residu). Oleh karenanya sebagi geenerasi penerus estafet kebudayaan maka kita wajib mengenal kebudayaan yang menjadi nilai warisan kebudian dengan kemudian mempertahankannya hingga tidak habis hilang oleh perkembangan zaman. Efektifitas kearifan lokal dalam mengambil peran perkembangan masyarakat disebabkan terutama oleh komunikasi strategis yang disuguhkannya, diantaranya melalui bahasa simbol yang cukup efektif. Kearifan lokal menjadi ciri dari suatu daerah yang perlu dilestarikan dan dijaga keasliannya. Keberlangsungan kearifan lokal di suatu wilayah dilakukan secara turun temurun satu generasi ke generasi berikutnya.
\end{abstract}

\section{Kata kunci: Local Wisdom, Globalisasi, Sumber Belajar IPS}

\section{A. Pendahuluan}

Kearifan lokal (local wisdom) adalah bagian dari budaya suatu masyarakat yang tidak dapat dipisahkan dari bahasa masyarakat itu sendiri. Kearifan lokal ini biasanya diwariskan secara turun temurun dari satu generasi ke generasi melalui cerita dari mulut ke mulut. Kearifan lokal ini terdapat pada cerita rakyat, peribahasa, lagu, dan permainan rakyat. Kearifan lokal merupakan suatu pengetahuan yang ditemukan oleh masyarakat lokal tertentu melalui kumpulan 
pengalaman dalam mencoba dan diintegrasikan dengan pemahaman terhadap budaya dan keadaan alam suatu tempat.

Indonesia merupakan bangsa yang memiliki keanekaragaman dalam berbagai hal. Salah satunya adalah budaya yang berkembang dalam masyarakat adat sebagai kekayaan nasional. Masyarakat adat secara tradisi terus berpegang pada nilai-nilai lokal yang diyakini kebenarannya dan menjadi pegangan hidup yang diwariskan secara turun temurun. Salah satu kearifan lokal yang masih bertahan ditengah-tebgah kehidupan masyarakat sekarang adalah kesenian karungut sansana atau karungut suku Dayak yang berasal dari Kalimantan Tengah. Meskipun kini kita tengah menghadapi era globalisasi dengan segala dampaknya kesenian tradisional masih terus bertahan dengan baik. Hak tersebut tak luput dari adanya berbagai pendekatan dengan mengerahkan semua potensi yang dimiliki sebuah bangsa, termasuk kearifan lokal suatu masyarakat adat. Sistem budaya lokal merupakan modal sosial (social capital)yang besar, telah tumbuh dan berkembangsecara turun-temurun yang hingga kini kuat berurat-berakar di masyarakat.Oleh karena itu, penting untuk melembagakan kembali(reinstitusionalisasi) kearifan lokal, mengingatperanannya dalam membantu penyelamatan lingkungan. Lingkungan hidup memang sedangmengalami degradasi sebagai dampak negatifdari lompatan petumbuhan jumlah pendudukyang tidak terkendali serta globalisasi.

\section{B. Metodologi Penelitian}

Adapun dalam analisis ini penulis menggunakan metodologi studi literatur yang dilakukan dengan cara mengkaji berbagai literatur yang sudah ada atau mencari referensi atas landasan teori yang relevan dengan kasus atau permasalahan yang ditemukan. Referensi tersebut bisa dicari dari buku, jurnal, artikel laporan penelitian, dan situs-situs online di internet. Dari pemaparan tersebut yang akan menjelaskan gambaran singkat dari apa yang telah dipelajari, argumentasi, dan ditetapkan tentang topik penelitian tertentu, yang biasanya diorganisasikan secara kronologis atau tematis. 


\section{Pembahasan/Analisis}

Kearifan lokal akan tetap bertahan jika masyarakat tetap mempertahankan serta melaksanakan pandangan, aturan, nilai, norma yang ada. Perkembangan budaya ditengah perkembangan zaman kadang membuat kearifan lokal semakin dilupakan oleh masyarakat. Namun, kearifan lokal ada dengan proses yang sangat panjang dan memiliki nilai-nilai leluhur yang ada didalamnya dengan adanya kebudayaan sebagai bukti konkrit. Nilai tersebut terdiri nilai historis, sosial, ekonomi, dan lingkungan. Nilai historis yakni keteladanan, keberanian, tanggung jawab, dan rela berkorban. Nilai sosial yakni solidaritas, kerja sama, gotong royong, kebersamaan dan sopan-santun. Nilai ekonomi yakni kemandirian, kesederhanaan, dan produktivitas.

Kearifan lokal dapat dipahami sebagai gagasan-gagasan setempat yang bersifat bijaksana, penuh kearifan, bernilai baik yang tertanam dan diikuti oleh anggota masyarakatnya. Keberadaan kearifan lokal ini memiliki fungsi. Fungsi yang dijelaskan Sartini (2006) bahwa fungsi kearifan lokal adalah:

1) konservasi dan pelestarian sumber daya alam;

2) pengembangan sumber daya manusia;

3) pengembangan kebudayaan dan ilmu pengetahuan;

4) petuah, kepercayaan, sastra dan pantangan;

5) bermakna sosial misalnya upacara integrasi komunal/kerabat;

6) bermakna etika dan moral; dan

7) bermakna politik.

Bentuk-bentuk kearifan lokal seperti kerukunan beragaman dalam wujud praktik sosial yang dilandasi suatu kearifan dari budaya. Keberlanjutan dan keseimbangan bentuk kearifan lokal dalam masyarakat dapat berupa budaya (nilai, norma, etika, kepercayaan, adat istiadat, hukum adat, dan aturan-aturan khusus). Nilai-nilai luhur terkait kearifan lokal yaitu cinta kepada Tuhan, alam semester beserta isinya, tanggung jawab, disiplin, dan mandiri, jujur, hormat dan 
santun, kasih sayang dan peduli, percaya diri, kreatif, kerja keras, dan pantang menyerah, keadilan dan kepemimpinan, baik dan rendah hati, toleransi, cinta damai, dan persatuan.

Kearifan lokal biasanya tercermin dalam kebiasaan-kebiasaan hidup masyarakat yang telah berlangsung lama. Atmodjo berpendapat kearifan lokal merupakan kemampuan penyerapan kebudayaan asing yang datang secara selektif artinya disesuaikan dengan suasana dan kondisi setempat (1986). Kemampuan demikian sangat relevan dengan tujuan masyarakat dapat memilih dan memilah budaya yang sesuai dengan karakteristik budaya sendiri. Kemampuan penyerapan kebudayaan asing yang datang secara selektif akan memerlukan pengalaman langsung dari masyarakat. Kearifan lokal yang berada di daerah seyogianya masih terjaga eksistensi. Dalam kearifan lokal terkandung makna kebersamaan dan bijaksana. Harapannya setiap kegiatan memperhatikan aspek kearifan lokal setempat serta mengedepankan konsep pemberdayaan masyarakat ini dapat dilakukan

Karungut merupakan salah satu jenis musik tradisional masyakat Ngaju di Kalimantan Tengah yang sedang mengalami pergeseran atau kemunduran. Seni ini berupa sastra lisan atau juga bisa disebut pantun yang dilagukan. Karungut merupakan karya yang dijunjung masyarakat Dayak sebagai sastra besar klasik dan merupakan semacam pantun atau gurindam. Pelantun karungut mengisahkan syair-syair kebajikan dengan meramu bermacam legenda, nasihat, teguran, dan peringatan mengenai kehidupan sehari-hari. Karungut sering dilantunkan pada acara penyambutan tamu yang dihormati. Salah satu ekspresi kegembiraan dan kebahagiaan diungkapkan dalam bentuk Karungut.

Dalam penelitian ini ditemukan tiga permasalahan sebagai penyebab kemunduran musik karungut, yaitu :

1) kurangnya minat generasi muda mempelajari musik karungut,

2) kurangnya campur tangan pemerintah terhadap pelestarian musik karungut,

3) belum adanya penelitian dan penggarapan musik karungut secara kusus, baik oleh para seniman, budayawan maupun para peneliti dibidang seni musik.

Karungut adalah salah satu kesenian tradisional yang sangat komunikatif, karena pesan-pesan yang disampaikan berbentuk pantun dalam bahasa daerah Dayak dan mudah dimengerti 
penontonnya. Karungut diiringi alat musik kecapi, bisa pakai band atau organ. Karungut semacam sastra lisan nusantara untuk Kalimantan Tengah sama dengan Madihin jika di Kalimantan Selatan. Sedangkan di Jawa Tengah disebut Macapat. Dengan kata lain karungut dapat dikatakan suatu irama lagu daerah Kalimantan Tengah untuk melagukan syair-syair atau naskah yang bukan berbentuk syair. Karungut dikenal di sepanjang jalur sungai Kahayan, Kapuas, Katingan, Rungan Manuhing dan sebagian jalur sungai Barito.

1. Sejarah

Karungut menjadi seni khas Kalimantan Tengah yang mempunyai arti dan makna yang sangat dalam untuk ritual dan untuk menyampaikan segala sesuatu sesuai dengan keperluannya. Dahulu karangut dinyanyikan para ibu untuk menidurkan putra-putrinya. Dewasa ini karungut dapat ditemui di tempat hajatan perkawinan maupun khitanan, untuk menyambut tamu penting, untuk kampanye pilkada dan lain-lain.

Adapun menurut kepercayaan suku Dayak di Kalimantan Tengah, pada zaman dahulu manusia diturunkan dari langit bersamaan palangka bulau (tetek tatum). Pada waktu berada di bumi, palangka bulau adalah alat untuk menurunkan manusia dari langit ke bumi oleh Ranying Hatalla langit atau dewa para petinggi suku Dayak. Maka dari itulah mulai adanya alunan suara atau tembang-tembang dan sejak itulah Karungut muncul. Bahasa yang digunakan dalam Karungut adalah bahasa Sangiang atau sejenis bahasa Ngaju yang sangat tinggi sastranya digunakan dalam upacara adat dan berkomunikasi dengan roh halus. Dalam kehidupan masyarakat Dayak yang melaksanakan upacara, khususnya upacara adat, keagamaan, perkawinan, dan syukuran selalu di warnai dengan kegiatan kesenian seperti tari Manasai Karungut, Karunya, Tandak Mandau, dan Deder.

Suku Dayak Ngaju (Biaju) sendiri merupakan suku asli di Kalimantan Tengah. Suku ngaju merupakan sub etnis dayak terbesar di Kalimantan tengah yang persebarannya cukup luas dan utamanya terkonsentrasi di daerah Kota Palangka Raya, Kabupaten Pulang Pisau, Kabupaten Gunung Mas, Kabupaten Kapuas dan di kabupaten lainnya di seluruh wilayah kalimantan tengah dapat ditemui suku Ngaju. Suku Ngaju secara administratif merupakan suku baru yang muncul dalam sensus tahun 2000 dan merupakan 27,3\% dari penduduk Kalimantan Tengah, sebelumnya suku Ngaju tergabung ke dalam suku Dayak dalam sensus 1930. Di Kalimantan tengah suku ngaju sebagian 
besar berprofesi sebagai peladang, pekebun, peternak, penambang emas dan pasir zirkon, Penginjil/Pendeta, pegawai pemerintah, pegawai swasta dan bidang birokrasi lainnya.

\section{Pendidikan Era Globalisasi}

Tak dapat kita pungkiri bahwa masyarakat milenial dalam kehidupan modern sekarang ini, dunia pendidikan dihadapkan pada berbagai tantangan dan perubahan yang sangat cepat, yang kadang kala kehadirannya sulit diprediksi. Menyikapi berbagai tantangan dan perubahan yang sangat cepat tersebut, menuntut kesigapan lembaga pendidikan untuk memiliki kemampuan antisipatif, adaptif dan loyalitas yang tinggi dalam berbagai kemungkinan yang terjadi sebagai konsekuensi dari adanya perubahan itu sendiri. Ketidakmampuan lembaga pendidikan maupun individual mengantisipasi dan beradaptasi dengan perubahan yang terus terjadi, cepat atau lambat akan menimbulkan keterpurukan, yang pada gilirannya akan habis ditelan oleh perubahan yang terus berguler. Harus diakui bahwa pula bahwa suatu lembaga pendidikan itu akan selalu dan terus berubah seiring dengan perubahan zaman, bahkan setiap saat lembaga pendidikan selalu menjadi fokus perhatian dan tak jarang menjadi sasaran ketidakpuasan masyarakat, bukan hanya menyangkut investasi dan kondisi kehidupan yang terus berubah, tetapi juga menyangkut kondisi dan suasana kehidupan masa kini dan masa datang.

Pada saat ini Indonesia sudah masuk dalam era globalisasi tersebut, dimana salah satunya ditandai dengan mudahnya masyarakat mendapatkan informasi dari berbagai belahan dunia sebagai akibat dari perkembangan teknologi yangbegitu pesat. Hal Ini membawa pengaruhpositif maupun pengaruh negatif bagi yangmenerimanya. Pengaruh positif globalisasiterhadap perubahan tata nilai dan sikap, menyebabkan adanya pergeseran nilai dansikap masyarakat yang semua irasional menjadirasional sedangkan pengaruh negatif globalisasiterhadap masyarakat adalah masyarakat merasadimudahkan dengan teknologi maju membuatmereka merasa tidak lagi membutuhkan oranglain dalam beraktifitas, dimana kadang merekalupa bahwa mereka adalah mahluk sosial yangperlu berinteraksi dengan sesamanya. MenurutTilaar (2009: 1) "perubahan global yang sedangterjadi, telah merupakan suatu revolusi global(globalisasi) yang melahirkan suatu gaya hidup(a new life style)”. Sedangkan ketika ditilik dari siisi podiifnya adanga 
globalisasi mampu membuka pemikiran masyarakat untuk berinovasi sehingga memunculkan ide-ide baru yang kreatif.

\section{Kearifan Lokal sebagai Sumber Belajar}

Kearifan lokal merupakan kemampuan penyerapan kebudayaan asing yang datang secara selektif, artinya disesuaikan dengan suasana dan kondisi setempat. Kemampuan tersebut sangat relevan dengan tujuan pembelajaran IPS,terutama karena peserta didik dapat memilihdan memilah budaya mana yang sesuai dengankarakteristik budayanya.Peserta didik sebagai generasi penerus yang hidup dalam waktu lain dengan problematika yang berbeda, tentu tidak akan begitu saja menerima warisan itu. Mereka akan melakukan pemilihan atau pengolahan kembali nilai-nilai yang diwariskan dan mengambil yang menurutnya paling cocok serta sesuai dengan kepentingan keselamatan dan kesejahteraan serta si berikut. Seleksi tersebut akan terjadi dengan baik melalui pembelajaran dengan menggunakan sumber belajar yang bermakna.

\section{Kesimpulan}

Dari berbagai pemaapran tersebut maka dapat kita tarik kesimpulan bahwa kearifan erat kaitannya dengan kebudayaan. Local wisdom atau kebudayaan ini berwujud berbagai bentuk yang dapat mewakili suatu daerah dan bagamana masyarakatnya.Salah satunya adalah kesenian karungut sansana yang merupakan khas dari kalimantan tengah yang mana seringkali dibawakan oleh masyarakat dayak dalam bahasa daerah atau sangiang. Kearifan lokal ini berbentuk musik tradisional yang berfungsi sebagai hiburan hibgga bernilai ibadah bagi kepercayaan yang menganutnya. Kearifan lokal sejatinya tak lepas dari sumber belajar yang mana objek kajian seni kedaerahan masuk didalamnya dan menjadi objek yang dapat siswa aplikasikan sebagai bahan pembelajaran. Rra globalisasi yang pesat menbuat sunber belajar menjadi lebih jauh menarik dimana tak hanya penyampaian ilmu namun dengan adanya kemenarikan dalam hal penyampaian materi pada siswa dengan memanfaatkan kebebasan dan teknologi yang meluas. 


\section{Daftar Refrensi}

Subiyakto, B., \& Mutiani, M. (2019). Internalisasi nilai pendidikan melalui aktivitas masyarakat sebagai sumber belajar ilmu pengetahuan sosial. Khazanah: Jurnal Studi Islam dan Humaniora, 17(1), 137-166.

Subiyakto, B., \& Mutiani, M. (2019). Internalisasi nilai pendidikan melalui aktivitas masyarakat sebagai sumber belajar ilmu pengetahuan sosial. Khazanah: Jurnal Studi Islam dan Humaniora, 17(1), 137-166.

Jumriani, J., Mutiani, M., Putra, M. A. H., Syaharuddin, S., \& Abbas, E. W. (2021). The Urgency of Local Wisdom Content in Social Studies Learning: Literature Review. The Innovation of Social Studies Journal, 2(2), 103-109.

Mutiani, M. (2018). Literasi Budaya Lokal Sebagai Wahana Edukasi Di Era Milenial.

Syaharuddin, S., \& Mutiani, M. (2020). Strategi Pembelajaran IPS: Konsep dan Aplikasi.

Subiyakto, B., \& Abbas, E. W. (2020). Strategi Pembelajaran IPS: Konsep dan Aplikasi.

Rahman, A. M., Mutiani, M., \& Putra, M. A. H. (2019). Pengaruh kompetensi pedagogik dosen terhadap motivasi belajar mahasiswa pendidikan IPS. Jurnal Darussalam: Jurnal Pendidikan, Komunikasi dan Pemikiran Hukum Islam, 10(2), 375-387.

Haryanto, N. I. D. N. (2014). Musik Karungut Dalam Tradisi Masyarakat Dayak Ngaju Di Kalimantan Tengah. Selonding, 5(5), 833.

Tresna Yunita, A., Rochmaningtiyas Caturputri, W., Daniel Christian Nuhan, F., \& Sophia Latuconsina, A. (2013). MUSIK KARUNGUT DALAM TRADISI MASYARAKAT DAYAK NGAJU DI KALIMANTAN TENGAH (Tahap 1).

Salim, K., Sari, M. P., Islam, J. M. P., \& Riau, S. A. K. (2014). Pengaruh Globalisasi Terhadap Dunia Pendidikan. Makalah Jurusan Manajemen Pendidikan Islam, STAI Abdurahman Kepulauan Riau. Page, 1-11. 